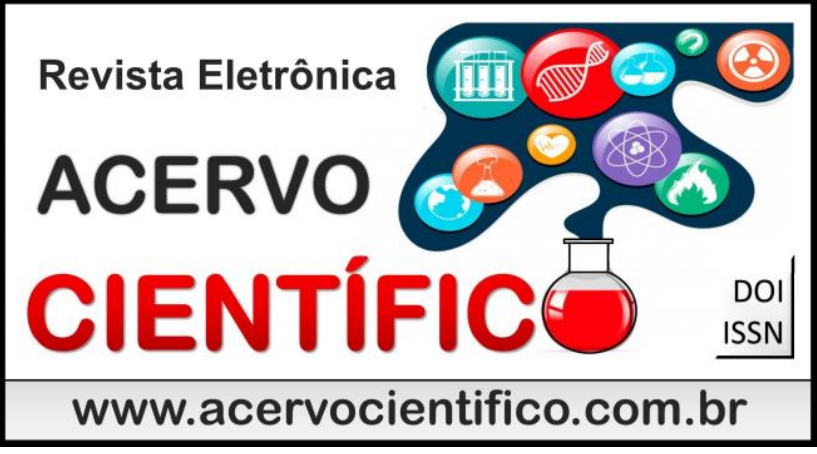

\title{
ORIGINAL
}

Recebido em: 12/2018

Aceito em: 12/2018

Publicado em: 3/2019

\section{IDENTIFICATION OF THE LIPIDS OF THE MICROALGAE CHLORELLA PYRENOIDOSA, AFTER OBTAINING THIS THROUGH USE OF BIOTECHNOLOGY}

Identificação dos lipídios da microalga Chlorella pyrenoidosa, após a obtenção desta através do uso da biotecnologia

Identificación de los lípidos de la microalga Chlorella pyrenoidosa, después de la obtención de ésta mediante el uso de la biotecnologia

Fabíola Ornellas de Araújo ${ }^{1-2}$, Reinaldo Giudici², João José Martins Simões de Sousa ${ }^{3}$

\begin{abstract}
Through the cultivation of the microalgae Chlorella pyrenoidosa was used the discontinuous biotechnological process, which was obtained a microalgal biomass (dry). This was directed to the supercritical processing apparatus, in which after use it was obtained an extract. This was analyzed to verify the types (varieties) of fatty acids in a gas chromatograph and also, it was coupled to mass spectrometry. It was noted that to perform the analysis in these two devices there was a complementarity between the results of types of fatty acids.
\end{abstract}

Keywords: Chlorella pyrenoidosa. Discontinuous biotechnological process. Microalgal biomass (Dry). Types (varieties) of Fatty Acids.

Resumo: Através do cultivo da microalga Chlorella pyrenoidosa fez-se o uso do processo biotecnológico descontínuo, o qual obteve-se a biomassa microalgal (seca). Esta foi direcionada ao aparelho de fluido supercrítico, em que após o uso foi obtido um extrato. Este foi analisado, em relação aos tipos (variedades) de ácidos graxos, em cromatógrafo à gas e também, o mesmo foi acoplado a espectrometria de massa. Notou-se que ao realizar análise nestes dois instrumentos houve uma complementariedade entre os resultados dos tipos de ácidos graxos.

Palavras-chave: Chlorella pyrenoidosa. Processo biotecnológico descontínuo. Biomassa microalgal (seca). Tipos (variedades) de ácidos graxos.

\footnotetext{
1 Department of Chemical Engineering, University of São Paulo, Av. Lineu Prestes 580, University City, 05508-090 São Paulo (SP), Brazil. *Corresponding author: ornellasfabiola@gmail.com

${ }^{2}$ Faculty of Pharmacy, University of Coimbra, Pólo das Ciências da Saúde, Azinhaga de Santa Comba, 3000-548 Coimbra, Portugal.
}

Financial support from CNPq (Process of postdoctoral fellowship: 167568/ 2017-5). 
Resumen: A través del cultivo de la microalga Chlorella pyrenoidosa se hizo el uso del proceso biotecnológico discontinuo, el cual se obtuvo la biomasa microalgal (seca). Esta fue dirigida al aparato de fluido supercrítico, en que después del uso se obtuvo un extracto. Este fue analizado, en relación a los tipos (variedades) de ácidos grasos, en cromatógrafo a gas y también, el mismo fue acoplado a espectrometría de masa. Se observó que al realizar análisis en estos dos instrumentos hubo una complementariedad entre los resultados de los tipos de ácidos grasos.

Palabras clave: Chlorella pyrenoidosa. Proceso biotecnológico discontinuo. Biomasa microalgal (seca). Tipos (variedades) de ácidos grasos.

\section{INTRODUTION}

The applicability of microalgae to pharmaceuticals may bring economic development to countries such as Brazil and Portugal, among others, which have considerable water resources for the production of algal and / or microalgal biomass.

Thus, man-made controlled cultivation of these aquatic organisms (algae) is a growing industry with great projection worldwide and this represents one of the most important food production activities for the near future, with frequent use of extracts are described in lists of ingredients present in pharmaceutical formulations (FAO, 1997; FAO, 2003).

That way the use of biotechnological techniques (discontinuous and / or discontinuous fed processes) and the acquisition of new, more sophisticated microalgal products may influence the development of new pharmaceutical supplies and / or new, more sophisticated finished products, with the aim of improving health. With this, using biotechnological techniques through biotechnological fermentation processes of macroalgae and microalgae is fundamental, for example, to improve the quality of the substances produced by the secondary metabolites, such as fatty acids.

Thus, the use of these raw materials from algae (macroalgae and microalgae) is considered the basis of the entire aquatic food chain (MÜLLER-FEUGA, 2000), especially microalgae, which represent numerous food products, not only for the aquatic organisms, but also for the human diet, serving as vitamin and protein supplements (LÜNING, 1990; BOROWITZKA, 1999; RODRIGUES, 2008). In this way these can be used as an important resource for obtaining natural products with high economic potential, for the food, pharmaceutical and cosmetic industries, some provide natural dyes, others have rich polyunsaturated fatty acids and abundant amounts of proteins, finally all these functions can help as an enriching source of finished products (RODRIGUES, 2008; HOBUSS et al., 2011).

The objective was to associate with biotechnology, with the implantation of natural components designated as "green, sustainable and technological cosmetics" it was essential to obtain formulations with characteristics that are more appropriate for human consumption and that preserve the environment. Maul (1998) reported on clean technology, with no residues, and on the use of non-toxic solvents, maintaining the original properties of the raw material without altering it, which proved to be an environmentally correct alternative, according to the obtaining of pharmaceutical supplies, using the supercritical fluid.

With this, it is essential to invest in research and develop new products derived from sustainable biotechnological processes for the consumer market. For example, like European countries, Brazil has a great demand for cosmetics, so it is essential to add scientific knowledge, for a common benefit among nations, to obtain a natural component through natural resources, where will be inserted in the cosmetics in the future.

This work is a continuation of a study carried out by the scientists Araújo, Giudici and Sousa, in 2019, in which the microalgae Chlorella pyrenoidosa were studied by discontinuous cultivation in shaker (Erlenmeyer flasks (hermetically sealed)) with adequate light intensity and agitation. Then, the extract from this microalga 
was obtained through a supercritical $\mathrm{CO}_{2}$ extraction process. Then, the extract from this microalga was obtained through a supercritical $\mathrm{CO}_{2}$ extraction process.

Therefore, the advantage of this process is to avoid wasting the use of solvents and to keep the compounds (components) thermosensitive (amino acids, vitamins, carotenoids, total phenolics, among others). These compounds from microalgal dry biomass can provide physicochemical properties (with cosmetic activity) to cosmetic formulations, such as: antioxidant, anti-inflammatory, regenerative, emollient, among others (REVERCHON, DONSI \& OSSEO, 1993; ROZZI \& SINGH, 2002; CASSANO et al., 2003; VAILLANT et al., 2005; CALVO, DADO \& SANTA-MARIA, 2007; ABBAS et al., 2008; ARAÚJO, 2015; USP, 2016; USP, 2017).

It should be noted that the last property mentioned above has an abundance of apolar components in its constitution (dry biomass processed in a supercritical fluid apparatus using the organic solvent $\left(\mathrm{CO}_{2}\right)$ ) (MAUL, 1998; REVERCHON, DONSI \& OSSEO, 1993; ROZZI \& SINGH, 2002) will provide emollient properties to the formulations and will function, for example, as an excellent moisturizer for dry skin (PRISTA, BAHIA \& VILAR, 1992; PRISTA, ALVES \& MORGADO, 2011).

\section{MATERIAL AND METHODS}

\section{PREPARATION OF THE INOCULUM/ MICROALGAL MATERIAL / DETERMINATION OF CELLULAR CONCENTRATION/ DETERMINATION OF PH/ BIOMASS EVALUATION OBTAINED/ BIOMASS EVALUATION OBTAINED/ DETERMINATION OF THE PROTEIN CONTENT OF BIOMASS $C$. pyrenoidosa/ DETERMINATION OF THE LIPID CONTENT OF BIOMASS $c$. pyrenoidosal DETERMINATION OF ASH CONTENT FOR C. PYRENOIDOSA/ DETERMINATION OF TOTAL CARBOHYDRATE CONTENT FOR $C$. pyrenoidosa}

The explanations, the main items are exposed in Araújo, Giudici and Sousa, in 2019.

In the present study was used the microalgae strain Chlorella pyrenoidosa (Chlorella sorokiniana) (UTEX, 1663) from the UTEX microalgae (The Culture Collection of Algae of the University of Texas at Austin U.S.A.) (UTEX, 2011).

\section{IDENTIFICATION AND QUANTIFICATION OF FATTY ACID COMPOSITION THROUGH GAS CHROMATOGRAPHY}

After determination of the lipid content of the biomass of $C$. pyrenoidosa, described by the scientists Araújo, Giudici and Sousa, in 2019, these carried out the identification and quantification of this composition of the fatty acids, using the gas chromatography technique.

Then, the transesterification of the fatty acids was performed with the objective of obtaining the conversion of the fatty acids into their respective methyl esters (HARTMAN \& LAGO, 1973). The sequence of the simplified steps to obtain the fatty acids were: use of the separation flask, to obtain the fatty acids; drying with gaseous nitrogen, in a rotary evaporator at $70^{\circ} \mathrm{C}$, to only remain the fatty acids; and the use of flasks (vails) with the obtained fatty acids, which were injected into the gas chromatograph (ARAÚJO, 2015; USP, 2016; USP, 2017).

Hartamn and Lago in 1973 proposed a transesterification methodology consisting of two steps: i) saponification (formation of soap after alkaline hydrolysis, that is, it is a reaction of an ester and an inorganic base (in this research $\mathrm{NaOH}$ was used in methanol solution), and (ii) esterification (the esterification reagent (ammonium chloride, methanol and concentrated sulfuric acid, warmed in a water bath for about 15 minutes) was used in this study. According to the Schuchardta, Serchelia and Vargas (1998) the summarized reaction can be described in Figure 1. 
Figure 1: Summary reaction of the transesterification process of the free fatty acids obtained through the round bottom flask (Adapted from SCHUCHARDTA, SERCHELIA \& VARGAS, 1998).

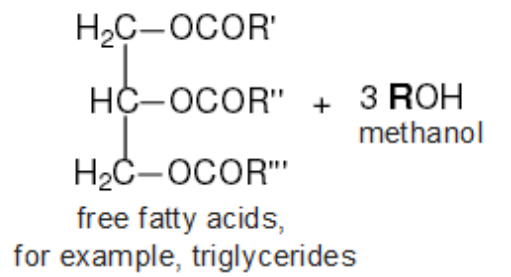

for example, triglycerides

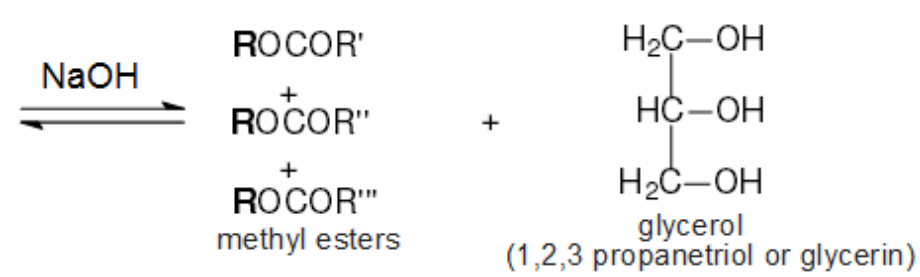

(1,2,3 propanetriol or glycerin)

Thus, this methodology recovered the lipid material that was in the separation flask by adding $5 \mathrm{~mL}$ of methanolic solution (Merck's pure analytical grade methanol with $0.5 \mathrm{~mol} \mathrm{~L}^{-1} \mathrm{NaOH}$ ). This mixture was directed to heating at reflux for 5 minutes. Subsequently, $15 \mathrm{ml}$ of the esterification reagent, composed of $2 \mathrm{~g}$ of ammonium chloride, $60 \mathrm{ml}$ of Merck's analytical grade methanol and $3 \mathrm{ml}$ of concentrated sulfuric acid were added. This mixture was heated in a water bath at $70^{\circ} \mathrm{C}$ for approximately 15 minutes. Thereafter, it was again directed to refluxing for a further 3 minutes, and directed to a separatory funnel, adding $25 \mathrm{~mL}$ of petroleum ether and $50 \mathrm{~mL}$ of deionized water. This mixture was shaken manually for 5 times and the phases were separated by decanting process with discard of the polar phase.

The collected (reserved) phase, that is, the phase of interest was directed to the rotavaporator, to be concentrated and the solvent to be evaporated. To this concentrate was added another $25 \mathrm{~mL}$ of deionized water, directed to the separation funnel again, with manual shaking five times (allow the decantation, to be able to separate the phases). The collected (reserved) phase, that is, the phase of interest was directed to the rotavaporator, to be concentrated and the solvent to be evaporated. To this concentrate was added another $25 \mathrm{~mL}$ of deionized water, directed to the separation funnel again, with manual shaking five times (allow the decantation, to be able to separate the phases). Then, to perform the analysis of the fatty acid methyl esters were analysed according to the methodology of Ract and Gioielli (2008), in which the samples were injected into the gas chromatograph, model 7890 CX (Agillent Technologies, USA) (Innowax_Agilent 19091N-133), equipped with a split-splitless type injector and FID (flame ionization detector) type detector, and the column used was polyethylene glycol (HP-Innowax) having $30 \mathrm{mx} 0.25 \mathrm{~mm} \times 0.25 \mu \mathrm{m}$ (length, internal diameter and film thickness, respectively).

The conditions of analysis were:

- Injection: $2 \mu \mathrm{L}$ of solubilized sample in $1.5 \mathrm{~mL}$ of HPLC purity hexane;

- Temperature programming: initial oven to $75^{\circ} \mathrm{C}$, which must be maintained for $1 \mathrm{~min}$, where the oven heating ramp varies from $37.5^{\circ} \mathrm{C} \cdot \mathrm{min}^{-1}$ to $150^{\circ} \mathrm{C}$, and $1^{\circ} \mathrm{C} \cdot \mathrm{min}^{-1}$ to $215^{\circ} \mathrm{C}$, then the final temperature was maintained for 10 minutes;

- Injector temperature: $250^{\circ} \mathrm{C}$;

- Detector temperature: $280^{\circ} \mathrm{C}$;

- Total running time 78 minutes, for each sample;

- Gás de arraste de alta pureza e quimicamente inerte: hélio (fluxo de $25 \mathrm{~mL} \mathrm{~min}^{-1}$ ), e a mistura de dois gases (ar sintético (fluxo de 120-160 mL. $\mathrm{min}^{-1}$ ) e $\mathrm{H}_{2}$ (fluxo de 200-210 mL.min-1), para o aquecimento do forno e produzir a queima);

- High purity and chemically inert entrainment gas: helium (flow $25 \mathrm{~mL}^{\mathrm{min}}{ }^{-1}$ ), and the mixture of two gases (synthetic air (flow of 120-160 mL. $\mathrm{min}^{-1}$ ) and $\mathrm{H}_{2}$ (flow of 200- $210 \mathrm{~mL} \cdot \mathrm{min}^{-1}$ ), for heating the furnace and producing the firing); 
The identification was performed by correlating the retention time of the constituents of the '37 Component FAME Mix'(Supelco) standard, with the retention time of the samples of the two photosynthetic micro-organisms injected into the gas chromatograph.

\section{IDENTIFICATION AND QUANTIFICATION OF COMPOSITION OF FATTY ACIDS, THROUGH GAS CHROMATOGRAPHY COUPLED TO MASS SPECTROMETRY}

After the lipid extraction the samples were analyzed in a gas chromatograph coupled to a mass spectrometer (CG MS QP 2010 Plus model, Shimadzu, with electron ionization (EI) ionization source (70 eV) and quadrupole analyzer. software used was GCMS-QP 2010 Series LabSolutions GC MSolution from Shimadzu®, which has a library with estimated mass-to-load ratio $(\mathrm{m} / \mathrm{z})$ of fatty acids.

The column used was DB5MS (5\% phenylmethyl-polysiloxane - $30 \mathrm{~m}$ long, $0.25 \mathrm{~mm}$ internal diameter and $0.25 \mu \mathrm{m}$ film thickness), with injections of $1 \mu \mathrm{L}$. The samples were analyzed using the following conditions of chromatographic analysis (Table 1) and mass spectrometry (Table 2) (Adaptation of ADAMS, 2009).

Tabela 1: Conditions of chromatographic analysis.

\begin{tabular}{c|c}
\hline Temperature of the injector & $280^{\circ} \mathrm{C}$ \\
\hline Interface temperature & $300^{\circ} \mathrm{C}$ \\
\hline Initial column temperature & $40^{\circ} \mathrm{C}$ \\
\hline Heating rate & $3^{\circ} \mathrm{C} / \mathrm{min}$ \\
\hline Final column temperature & $300^{\circ} \mathrm{C}$ \\
\hline Total anlysis time & $86,67 \mathrm{~min}$ \\
\hline
\end{tabular}

Tabela 2: Conditions of mass spectrometry.

\begin{tabular}{c|c}
\hline Solvent cutting & $10 \mathrm{~min}$ \\
\hline Mass range & $35-700 \mathrm{~m} / \mathrm{z}$ \\
\hline Font temperature & $300^{\circ} \mathrm{C}$ \\
\hline Scan Speed & 2500 \\
\hline Heating rate & $5^{\circ} \mathrm{C} / \mathrm{min}$ \\
\hline Final column temperature & $280^{\circ} \mathrm{C}$ \\
\hline Maintenance at $280{ }^{\circ} \mathbf{C}$ & $14 \mathrm{~min}$ \\
\hline Total analysis time & $60 \mathrm{~min}$ \\
\hline
\end{tabular}

\section{RESULTS AND DISCUSSION}

The identification and quantification of lipids in the dry biomass of $C$. pyrenoidosa were carried out. For these identifications, the best culture media were used based on Araújo's studies carried out in 2015, which resulted in biomasses, with the highest lipoprotein levels (when correlated with the other culture media used. 
This research is a continuation of the study conducted by the scientists Araújo, Giudici and Sousa, in 2019, in which the independent variable was the microalgae (C. pyrenoidosa). The dependent variable (response, result), which was measured in this research was the content of fatty acids (fatty acid profiles).

In all the experiments of this research the results were evaluated through analysis of variance (one-way ANOVA), using the Tukey tests applied with 95\% confidence interval, using the program Statistic 11.0 and obtaining the evaluations, in relation to percentages of fatty acid profiles and amino acid profiles.

The use of resources from microalgae $C$. pyrenoidosa in the area of biotechnology is an important way of obtaining raw material rich in fatty acids as a way of supplying what is necessary for human health or other anthropogenic means (industries such as cosmetics, food, among others).

Thus, an analysis was performed in triplicate. The results obtained for this microalgae were: saturated (AGS), monounsaturated (AGMI), polyunsaturated fatty acids (PUFA), unsaturated fatty acids and unsaturated fatty acids and saturated fatty acid (AGPI / AGS) (Table 3).

Tabela 3: Fatty acid profile (\%) after shaker cultivation. Test performed in triplicate. ${ }^{*}$ The values presented as mean \pm standard deviation. The results were obtained through analysis of variance (ANOVA one-way), followed by the Tukey test, with a confidence interval of $95 \%$. Different letters in the same column represent statistically different values.

\begin{tabular}{cc}
\hline Fatty acid (\%) $^{*}$ & C. pyrenoidosa \\
\hline C14:0 & $0,88 \pm 0,14^{\mathrm{A}}$ \\
C16:0 & $24,01 \pm 0,22^{\mathrm{B}}$ \\
C16:1 & $7,04 \pm 0,01^{\mathrm{C}}$ \\
C17:0 & $1,94 \pm 0,01^{\mathrm{D}}$ \\
C17:1 & $1,86 \pm 0,03^{\mathrm{D}}$ \\
C18:0 & $13,54 \pm 0,02^{\mathrm{E}}$ \\
C18:1n9C & $7,76 \pm 0,13^{\mathrm{F}}$ \\
C18:2n6c & $18,36 \pm 0,11^{\mathrm{G}}$ \\
C18:3n6 & $24,61 \pm 0,30^{\mathrm{H}}$ \\
\hline AGS & 40,37 \\
\hline AGMI & 16,66 \\
\hline AGPI & $\mathbf{4 2 , 9 7}$ \\
\hline AGPI/AGS & $\mathbf{1 , 0 6}$ \\
\hline
\end{tabular}

*Percentage of fatty acids in relation to total (mass/mass).

According to the Dunstan and collaborators (1993) and Miao and Wu (2004), a concentration variation of the compositions between the fatty acids in the microalgae biomass may occur, depending on some factors, such as growth, culture medium, temperature, $\mathrm{pH}$, salinity, luminous intensity, as well as the beginning of the cultivation and the end, which can reveal different amounts of each of the fatty acids in the biomass to be analyzed. 
The biochemical composition of the microalgae biomass is not only determined by the nature of each algal species, depending on factors such as light intensity, temperature, $\mathrm{pH}$, nutrients and agitation (MIAO \& $W U, 2004)$. These can contribute, for the optimization of the cultivation, because the growth of microalgae derives from several biochemical and biological reactions (BENEMANN, 1990; BENEMANN \& OSWALD, 1996; RICHMOND, 2004).

Thus, the content of polyunsaturated fatty acids produced by the microalga can be determined by the cultivated species, nutrient concentration of the culture medium, aeration flux, luminosity, photoperiod time and crop temperature, seasonal variation (seasonality) and circadian cycle, among others (FLYNN \& BUTLER, 1986; LOUGHRIN et al., 1991; VONSHAK \& TORZILLO, 2008; GROBBELAAR, 2010).

It can be extracted from table 3, that the results predominate in: C18:3n6 $\gamma$-linolenic acid (omega 6 or $\omega$ 6); C16:0 (palmitic acid); C18: 2n6c linoleic acid (omega 6 or $\omega-6$ ), and C18:0 (stearic acid), respectively, $(24.61 \pm 0.30 \%) ;(24.01 \pm 0.22 \%) ;(18.36 \pm 0.11 \%)$ and $(13.54 \pm 0.02 \%)$.

The highest concentrations of the fatty acids were: polyunsaturated $(\mathrm{C} 18: 2 \mathrm{n} 6 \mathrm{c}$ (linoleic fatty acid (omega 6 or $\omega-6)$ ) and C18:3n6 $\gamma$-linolenic acid (omega 6 or $\omega-6$ ); and saturated fatty acids (sum of C18:0 (stearic fatty acid) and C16:0 (palmitic fatty acid)), these results corroborated with literature data reported by Petkov and Garcia in 2007 under three different culture conditions, for the microalgae $C$. pyrenoidosa, whereas the monounsaturated fatty acids (C16:1 palmitoleic acid, C17:1 cis-10-heptadecenoic acid, C18:1n9c oleic acid (omega 9 or $\omega-9)$ ) resulted in approximately 16, $7 \%$, in relation to the total (mass / mass). However, when these results of this current research were correlated with the data obtained by the same scientists, it was observed that the fatty acids: (C16:1) and (C18:1n9c), except for fatty acid (C17:1), (phototrophic, phototrophic without addition of $\mathrm{N}$ and heterotrophic) were similar only for the heterotrophic $(\mathrm{C} 16: 1)$ and the closest value for $\mathrm{C} 18: 1 \mathrm{n} 9 \mathrm{c}$ ) was used for the phototrophic cultivation without addition of N. Chisti (2007) when doing the phototrophic cultivation without addition of $\mathrm{N}$ was equal to the value obtained in this current research, approximately $8 \%$ for $\mathrm{C} 18$ : $1 \mathrm{n} 9 \mathrm{c}$; which also reported in their studies that microalgae varied from 25 to $60 \%$ of polyunsaturated fatty acids in dry biomass, which corroborated with this research that presented approximately $43 \%$.

C14:0 Myristic acid; C16:0 palmitic acid; C16:1 palmitoleic acid; C17:0 Marginic acid; C17: 1 cis-10heptadecenoic acid; C18:0 Stearic acid; C18:1n9c oleic acid (omega 9 or $\omega-9$ ); C18:2n6c linoleic acid (omega 6 or $\omega-6$ ); C18:3n6 $\gamma$-linolenic acid (omega 6 or $\omega-6$ ). AGS: saturated fatty acid; AGMI: monounsaturated fatty acid; PUFA: polyunsaturated fatty acid (PUFA); AGPI/AGS: ratio between unsaturated fatty acid and saturated fatty acid.

However, depending on the parameters (seasonality (date of collection), circadian cycle (collection time), temperature of the growing room, among others), the estimated results, in relation to the amounts of fatty acids, may be reproducible and/or not, because it is a natural component (extract of photosynthetic microorganism) (ARAÚJO, 2015).

After some tests with different methodologies, with different solvents, performed in the gas chromatograph coupled to the mass spectrometer, such as the adapted method of Masood, Stark and Salem (2005) ( $1 \mathrm{mg}$ of sample, $150 \mu \mathrm{l}$ of methanol, $4,3 \mu \mathrm{l}$ of water, 8,6 $\mu \mathrm{l}$ of acetyl chloride). The dispersion was vortexed for 1 minute and heated at $50^{\circ} \mathrm{C}$ for $60 \mathrm{~min}$. After reaching room temperature $\left(25^{\circ} \mathrm{C}\right)$, the samples were centrifuged at $13400 \mathrm{xg}$ for $2 \mathrm{~min}$, in which the upper phase was collected and analyzed via GC-MS. And the latter method was performed an adaptation of Bignognoa et al., 2002, which used the solvent $\mathrm{n}$ hexane.

This solvent is the most popular and most used in the extraction of lipids for food application, and which has been obtained the largest number of fatty acids detected. Since the components extracted by this solvent are hydrocarbons, triacylglycerols and fatty acids (MOLINA et al., 1999; KOVALCUKS \& DUMA, 2014).

Thus, $1 \mathrm{mg}$ of sample was used, which was resuspended in $150 \mu \mathrm{l}$ of $\mathrm{n}$-hexane, then the vortex was used for 1 minute. In the next step, the samples were centrifuged at $13400 \mathrm{xg}$ for 2 min (Adaptation of 
BIGOGNOA et al., 2002).

The fatty acids were identified (estimated or analyzed) via GC-MS (Gas Chromatography coupled to Mass Spectrometry), through the mass ratio on the load $(\mathrm{m} / \mathrm{z})$, the fatty acids of the supercritical fluid extract of microalgae $C$. pyrenoidosa (tabela 4).

Tabela 4: Identification of fatty acids (mass/charge estimation), present in the supercritical fluid extract of $C$. pyrenoidosa, after shaker cultivation.

\begin{tabular}{ll}
\hline & \multicolumn{1}{c}{ Fatty acids $^{*}$} \\
\hline C4:0 & butanoic acid \\
C8:0 & octanoic acid \\
C10:0 & nonanoic acid (pelargonium) \\
C12:0 & n-decanoic acid \\
C13:0 & dodecanoic acid \\
C14:0 & tridecanoic acid \\
C15:0 & 9-tetradecanoic acid \\
C16:0 & pentadecanoic acid \\
C17:1 & hexadecanoic acid (palmitic acid) \\
C18:0 & heptadecanoic acid \\
C18:1n9c & octadecanoic acid or stearic acid \\
C20:3 & oleic acid ( $\omega$-9) \\
C20:0 & 8,11,14-eicosatrienoic acid $(\omega-6)$ \\
\hline
\end{tabular}

* Type of fatty acids, present in the microcrystalline supercritical fluid extract ( $C$. pyrenoidosa), estimate between (mass / load).

\section{CONCLUSION}

This research made use of Biotechnology and is a continuation of the studies obtained by the scientists Araújo, Giudici and Sousa, in 2019, thus, different proportions of fatty acids were observed in the lipid fractions of this microalga studied here. Thus, it was noted that for the different types of fatty acids, using the best culture medium (C. pyrenoidosa), which was Bold $+7 \mathrm{mM}$ of $\mathrm{NaNO}_{3}$ and $7 \mathrm{mM}$ of $\left(\mathrm{NH}_{4}\right)_{2} \mathrm{SO}_{4}$ (described in Araújo, Giudicia and Sousa, in 2019) were: saturated fatty acid (AGS) $=40.37 \%$, monounsaturated fatty acid $(A G M I)=16.66 \%$, polyunsaturated fatty acid $(P U F A)=42.97 \%$, and in relation to to the ratio of unsaturated fatty acid to saturated fatty acid (AGPI / AGS) $=1.06$.

The results for gas chromatography coupled to mass spectrometry (mass-to-charge ratio $(\mathrm{m} / \mathrm{z})$ ) and correlation with library data from Shimadzu® GCMS-QP 2010 Series LabSolutions GC MSolution software were estimated to be 14 types of acids fatty acids, which were described in Table 4.

Thus, this research revealed the best results for obtaining a biomass rich in lipoprotein, and with this it was possible to identify and quantify the fatty acids, with satisfactory results.

Therefore, as described by scientists Araújo, Giudici and Sousa, in 2019, obtaining a natural raw material (of quality and safety) will depend on many parameters such as temperature, luminous intensity, sources of 
nutrients, $\mathrm{pH}$, among other factors. Thus, the use of all parameters in obtaining a natural quality and safe raw material, coupled with the most modern, correct and appropriate analysis techniques, will make the whole process probably reproducible and stable.

\section{ACKNOWLEDGMENTS}

The authors acknowledge the financial support from CNPq (Process of postdoctoral fellowship: 167568/ 2017-5).

\section{REFERENCES}

1. ABBAS KA, MOHAMED A, ABDULAMIR AS et al. A review on supercritical fluid extraction as new analytical method. Am. J. Biochem. Biotechnol. 4: 345-353. 2008.

2. ADAMS RP. Identification of essential oil components by gas chromatographyl mass spectrometry. $4^{\text {th }}$ Ed. Carol Stream: Allrued books. 2009. 804p.

3. ARAÚJO FO. Avaliação do crescimento e composição de micro-organismos fotossintetizantes para uso como matéria-prima em fotoprotetor. 2015. Tese-FCF. Univ. de São Paulo. 215p.

4. ARAÚJO FO, GIUDICI R, SOUSA JJM. Cultivation of the microalgae Chlorella pyrenoidosa using the processes of Biotechnology. Revista Eletrônica Acervo Científico/ Eletronic Journal Science Collection. 2: e121, 2019.

5. BENEMANN JR. Microalgae products and production: an overview. Journal of Industrial Microbiology. 31: 247256. 1990.

6. BENEMANN JR, OSWALD WJ. Systems and Economic Analysis of Microalgae Ponds for Conversion of $\mathrm{CO}_{2}$ to Biomass, Final Report, Pittsburgh Energy Technology Center. 1996. 260p

7. BIGOGNOA C, KHOZIN-GOLDBERGA I, BOUSSIBAA S, VONSHAKA, et al. Lipid and fatty acid composition of the green oleaginous alga Parietochloris incisa, the richest plant source of arachidonic acid. Phytochemistry. 60: 497-503. 2002.

8. BLIGH EG, DYER WJ. A rapid method of total lipid extraction and purification. Canadian Journal of Biochemistry Physiology. 37: 911-917. 1959.

9. BOROWITZKA MA. Commercial production of microalgae: ponds, tanks, tubes and fermenters. Journal of Biotechnology. 70: 313-321. 1999.

10. CALVO MM, DADO D, SANTA-MARIA G. Influence of extraction with ethanol or ethyl acetate on the yield of lycopene, $\beta$-carotene, phytoene and phytofluene from tomato peel powder. Eur. Food Res. Technol. 224: 567571. 2007.

11. CASSANO A, DRIOLI E, GALAVERNA G, et al. Clarification and concentration of citrus and carrot juices by integrated membrane processes. Journal of Food Engineering. 57: 153-163. 2003.

12. PETKOV G, GARCIA G. Which are the fatty acids of the green alga Chlorella. Biochem. Syst. Ecol. 35: 281285. 2007.

13. DUNSTAN GA, VOLKMAN JK, BARRETT SM, et al. Changes in the lipid composition and maximisation of the polyunsaturated fatty acid content of three microalgae grown in mass culture. J. Appl. Phycol. 5: 71-83. 1993.

14. FAO. El Estado Mundial de la Pesca y la Acuicultura, 1996. Food and Agricultural Organization of the United Nations. Roma, Italia. 1997.

15. FAO. A guide to the seaweed industry. Food and Agricultural Organization of the United Nations. Roma, Itália. 105p. 2003.

16. FLYNN KJ, BUTLER I. Nitrogen sources for the growth of marine microalgae: role of dissolved free amino acids. Mar. Ecol. Prog. Ser.. 34: 281-304. 1986.

17. GROBBELAAR JU. Microalgal biomass production: challenges and realities. Photosynthesis Research. 106: 135-144. 2010. [Review].

18. HARTMAN L, LAGO RC. Rapid preparation of fatty acid methyl esters from lipids. Lab. Prat.. 22: 475-476. 1973.

19. HOBUSS CB, ROSALES PF, VENZKE D, et al. Cultivation of algae in photobioreator and obtention of biodiesel. Revista Brasileira de Farmacognosia Brazilian Journal of Pharmacognosy. 21: 361-364. 2011. 
20. KOVALCUKS A, DUMA M. Solvent extraction of egg oil from liquid egg yolk. $9^{\text {th }}$ Baltic Conference on Food Science and Technology "Food for Consumer Well-Being". Jelgava. FOODBALT. 253-256. 2014.

21. LOUGHRIN JH, HAMILTON-KEMP TR, ANDERSEN RA, et al. Circadian rhythm of emission from flowers of Nicotiana sylvestris and N. suaveolens. Physiol. Plant.. 83: 492-496. 1991.

22. LÜNING K. Seaweeds, their environment, biogeography and ecophysiology. John Wiley and Sons, Inc. New York. 1990.527 p.

23. MAUL AA. Extração de insumos farmacêuticos por fluido supercrítico. 1998. Dissertação-FCF. Univ. de São Paulo. 142p.

24. MIAO X, WU Q. High yield bio-oil production from fast pyrolysis by metabolic controlling of Chlorella protothecoides. Journal of Biotechnology. 110: 85-93. 2004.

25. MOLINA GRIMA E, GARCIA CAMACHO F, ACIEN FERNANDEZ FG. Production of EPA from Phaeodactylum tricornutum. In: COHEN, Z. (Ed.), Chemicals from Microalgae. Taylor and Francis, London. 1999. 57-92 p.

26. MASOOD A, STARK KD, SALEM NJR. A simplified and efficient method for the analysis of fatty acid methyl esters suitable for large clinical studies. Journal of Lipid Research. 46: 2299-2305. 2005.

27. MÜLLER-FEUGA A. The role of microalgae in aquaculture: situation and trends. Journal of applied phycology. 12: 527-534. 2000.

28. PRISTA LN, BAHIA MFG, VILAR E. Dermofarmácia e cosmética. Porto Associação Nacional das Farmácias. 1992. 1: 15-136.

29. PRISTA LN, ALVES AC, MORGADO R. Técnica farmacêutica e farmácia galênica. 8 ed. Lisboa. Fundação Calouste Gulbenkian. 786p. 2011.

30. RACT JNR, GIOIELLI LA. Lipídios modificados obtidos a partir de gordura do leite, óleo de girassol e ésteres de fitosteróis para aplicação em spreads. Quím. Nova. 31: 1960-1965. 2008.

31. REVERCHON E, DONSI G, OSSEO LS. Modeling of supercritical fluid extraction from herbaceous matrices. Ind. Eng. Chem. Res. 32: 2721-2726. 1993.

32. RICHMOND A. Handbook of microalgal culture: biotechnology and applied phycology. Oxford: Black Well Science. 2004. 566p.

33. RODRIGUES MS. Avaliação do cultivo de Spirulina platensis utilizando simultaneamente nitrato de potássio e cloreto de amônio como fontes de nitrogênio. Dissertação de Mestrado-FCF. 2008. Univ. de São Paulo. 149 p.

34. ROZZI NL, SINGH RK. Supercritical fluids and the food industry.Compr. Rev. Food Sci. Food Saf. 1:33-44. 2002.

35. SCHUCHARDTA U, SERCHELIA R, VARGAS MR. Transesterification of Vegetable Oils: a Review. J. Braz. Chem. Soc.. 9: 199-210. 1998.

36. UNIVERSIDADE DE SÃO PAULO (USP-SP). ARAÚJO FO, CARVALHO JCM, BABY AR, et al. "Formulação cosmética e seu uso, e uso de proteína hidrolisada de micro-organismos fotossintetizantes para a preparação de formulações cosméticas". BR10201602023-2. 08 de novembro de 2016. Revista da Propriedade Industrial - RPI №. 2392, p. 123. 2016.

37. UNIVERSIDADE DE SÃO PAULO (USP-SP). ARAÚJO FO, CARVALHO JCM, BABY AR, et al. "Formulação cosmética e seu uso, e uso de extrato de micro-organismos fotossintetizantes para a preparação de formulações cosméticas". BR102016004203-8. 29 de outubro de 2017. Revista da Propriedade Industrial RPI №. 2434, p. 597-598. 2017.

38. UTEX. The Culture Collection of Algae (1663; 2011). Disponível em: http://web.biosci.utexas.edu/utex/default.aspx/. Acessado em 23 dez. 2011.

39. VAILLANT F, CISSE M, CHAVERRI M, et al. Clarification and concentration of melon juice using membrane processes. Innovative Food Sciences \& Emerging Technologies. 6: 213-220. 2005.

40. VONSHAK A, TORZILLO G. Environmental Stress Physiology. In: RICHMOND, A. (ed.). Handbook of Microalgal Culture: Biotechnology and Applied Phycology. Blackwell Science. 2008. 57-82 p. 